\title{
Distribution of naturally occurring uranium and other heavy toxic elements in selected spring water samples of Pithoragarh District, Uttarakhand, India
}

\author{
Kiran Patni ${ }^{1,2}$ (1) $\cdot$ Chitra Pande $^{1} \cdot$ Ashutosh Pratap Pande $^{3} \cdot$ Geeta Tewari $^{1} \cdot$ Tanuj Joshi $^{4}$
}

Received: 12 August 2020 / Accepted: 23 November 2020 / Published online: 2 December 2020

(c) Springer Nature Switzerland AG 2020

\begin{abstract}
The main purpose of this study was to investigate the seasonal variation of the uranium (U) concentration level in natural drinking water. Laser fluorimetry technique has been used for the microanalysis of uranium concentration in water samples collected from different natural sources like springs and subterranean springs of various depths. A total of 23 drinking water samples were collected based on their consumption for drinking purposes from the different areas of Pithoragarh district. Seventeen physico- chemical parameters, six heavy metals and uranium were estimated in the samples. The results showed that the average value of TDS was observed $204.65 \mathrm{mg} / \mathrm{L}$ during pre- monsoon season and $213.82 \mathrm{mg} / \mathrm{L}$ during post- monsoon season, the uranium concentration in drinking water samples varied from $0.10-9.90 \mu \mathrm{g}^{\mathrm{L}-1}$ in premonsoon and $0.10-8.32 \mathrm{\mu g} \mathrm{L}^{-1}$ in post-monsoon seasons. The study revealed that none of the samples had exceeded the guideline values prescribed for concentration of uranium in drinking water by World Health Organization $\left(30 \mu \mathrm{g} \mathrm{L}^{-1}\right)$ and sources can be considered safe with respect to the level of uranium concentration.
\end{abstract}

Keywords Uranium concentration · Laser fluorimetry · Natural drinking water $\cdot$ Heavy metals

\section{Introduction}

Water is a vital component for the survival of life and is a universal solvent that can dissolve many organic and inorganic compounds [1]. The availability of clean and safe drinking water is a basic right of humans, but in the present scenario clean and safe drinking water is in scarcity. Water is an important element for life and has multiple uses especially for drinking purposes. Therefore, clean and safe drinking water is a vital commodity required for humans. Springwater is a common source of public supply in various rural communities [2]. In hills, spring water is frequently used for drinking purposes, therefore, the quality of spring water assumes the highest priority.
Human beings are exposed to natural radioactivity since the inception of the earth which is due to the presence of naturally occurring radionuclides in the surroundings. Exposure to radiation due to natural sources is a continuous and inescapable feature of life on earth [3]. Uranium is one of the radionuclides which is omnipresent and is widely available in the earth's crust. These radionuclides get introduced into the human body through food, water, and air. Uranium is present in rocks and soil and when water passes through and over these formations, it dissolves many compounds and minerals including uranium [4]. Most of the natural water sources contain a detectable concentration of uranium in the soluble or particulate form [5]. Uranium is radiologically toxic as well as chemically toxic and the level of toxicity depends

Kiran Patni, 93kiranpatni@gmail.com | ${ }^{1}$ Department of Chemistry, D. S. B. Campus, Kumaun University, Nainital, India. ${ }^{2}$ Graphic Era Hill University, Bhimtal, India. ${ }^{3}$ Department of Chemistry, L.S.M.G.P.G. College, Pithoragarh, India. ${ }^{4}$ Department of Pharmaceutical Sciences, Bhimtal, Kumaun University, Nainital, India. 
upon the concentration, exposure route, chemical nature, exposure period, the solubility of a uranium compound, contact time, and route of elimination from the body [6]. The chronic presence of uranium at higher concentrations in drinking water can cause severe health effects because of its non- biodegradable nature. Uranium congregates in vital human organs and results in toxicity. Along with this, uranium emits alpha particles of high ionizing power, so it may be toxic if inhaled or ingested in excess amount. Eighty five percent of ingested uranium is contributed through drinking water and only $15 \%$ is contributed through food [7]. Uranium is a well-known nephrotoxic element and the principal sites of its deposition in the body are the kidney, liver, and bones. Moreover, experimental studies show that the toxic effect of uranium is found on the respiratory and reproductive systems also $[8,9]$. Due to all these health hazards, the estimation of uranium in drinking water becomes very important. WHO guidelines have recommended a value of $30 \mu \mathrm{g} / \mathrm{L}$ (chemically) and Atomic Energy Regulatory Board (AERB), Department of Atomic Energy, India has recommended a value of $60 \mu \mathrm{g} / \mathrm{L}$ (radiologically) for the uranium concentration in drinking water [10, 11].

Uranium diffuses readily in oxygenated water due to which uranium is present in most of the surface, underground, and seawater. Studies have shown that weathering of igneous rocks from the earth's original crust results in a higher level of dissolved uranium concentration in comparison to other rock formations [12]. Along with this, combustion of coals, the use of phosphate fertilizers and effluents from the uranium industry are also responsible for the introduction of uranium in the water body [12]. Uranium exists in +4 oxidation state in primary igneous rocks, which further oxidize to +5 and +6 oxidation state. In +6 oxidation state, it is highly stable and soluble in water, while almost all compounds of uranium in +4 oxidation state are relatively insoluble in water. Uranium in +6 oxidation state forms uranyl $\mathrm{UO}_{2}^{+2}$ ions. This ion plays a very important role in transporting uranium through the weathering of rocks $[13,14]$. In the last few years, several studies have been undertaken in various states of India including Mansa district of Punjab; Balod district of Chattisgarh; Amritsar, Gurdaspur, and Pathankot districts of Punjab and Kanker district of Chattisgarh for the assessment of uranium concentration in groundwater and varied results were obtained from the studies [15-18].

Springwater is the prime source providing and regulating life at hills and being used as the main source of fresh drinking water at Uttarakhand. Various natural water sources like snow, spring, rain-fed rivers, lakes are a profound source of water in Uttarakhand [19]. Spring is a concentrated discharge of groundwater appearing at the ground surface as a current of flowing water. And when the ground surface intersects the water supply, the springs are formed [20]. Water pollution not only affects water quality but also harms human health, economic development, social structure, etc. During the evaluation of water quality, it also becomes very essential to evaluate the physico-chemical parameters to collect the very first information regarding the potability of water.

Keeping in view, all the health effects caused due to different pollutants in water and toxicity due to uranium, the present research work has been done to evaluate the water quality of the samples. A total of 24 parameters was evaluated in the water samples collected from various regions of Pithoragarh district, which includes physicochemical properties, uranium concentration as well as detection of the concentration of some other heavy metals. To the best of our knowledge, such type of study has not been conducted earlier in this region specifically for natural water sources only, so this baseline data will serve as reference information to assess any further changes in the concentration of uranium radionuclide as well as other parameters for future studies.

\section{Materials and methods}

\subsection{Geology of the study area}

The selected study region of Pithoragarh district covers the area between latitude $29.52-30.11^{\circ}$ and longitude $80.04-80.62^{\circ}$. It was situated in elevation of $<1150 \mathrm{~m}-2300 \mathrm{~m}$. Generally, the major sources of uranium are rocks, combustion of coals, use of phosphate fertilizers, effluents from the uranium industry but in the present study area, the only possible source of uranium can be rocks. The major rock types of the area are igneous, metamorphic, and sedimentary. Out of 23 sampling sites, 4 sites belong to an igneous type of rocks, 10 sites having metamorphic types of rocks, and 9 sites having sedimentary types of rocks. The district is distributed in six tehsils viz., Dharchula, Berinag, Munsyari, Pithoragarh, Gangolihat, and Didihat. The lands in the surroundings of the study area are being used for agricultural purposes throughout the year. The map of the study region and the major rock types of the surroundings of the study area are represented in Table 1 and Fig. 1.

\subsection{Experimental techniques}

The samples were collected in clean double capped polypropylene $250 \mathrm{~mL}$ bottles. 23 samples were collected from various springs and subterranean springs of various depths. The samples were collected in pre-monsoon (PRM) and post-monsoon (POM) seasons. For PRM, the sampling 
Table 1 Sampling sites with geological information

\begin{tabular}{|c|c|c|c|c|}
\hline \multirow[t]{2}{*}{ Tehsil (T) } & \multirow[t]{2}{*}{ Location details } & \multicolumn{2}{|c|}{$\begin{array}{l}\text { GPS Coordinate (WGS 84, } \\
\text { decimal) }\end{array}$} & \multirow[b]{2}{*}{ Type of rocks } \\
\hline & & Latitude & Longitude & \\
\hline Dharchula (T) & Khet & 29.99544 & 80.56699 & Igneous \\
\hline Dharchula $(T)$ & Baluwakot & 29.80225 & 80.43023 & Metamorphic \\
\hline Dharchula (T) & Pangu & 29.98328 & 80.61628 & Sedimentary \\
\hline Didihat (T) & Borabunga & 29.76568 & 80.21696 & Igneous, Plutonic \\
\hline Didihat $(\mathrm{T})$ & Chana & 29.752 & 80.23682 & Metamorphic \\
\hline Didihat $(\mathrm{T})$ & Tana/ Dugda & 29.71035 & 80.20463 & Sedimentary Carbonate \\
\hline Didihat $(\mathrm{T})$ & Askot & 29.76511 & 80.3313 & Igneous \\
\hline Didihat (T) & Suni & 29.74158 & 80.13281 & Metamorphic \\
\hline Didihat ( $\mathrm{T}$ ) & Sadgad & 29.66131 & 80.27119 & Sedimentary Carbonate \\
\hline Didihat (T) & Tarigaon & 29.79071 & 80.1373 & Metamorphic \\
\hline Berinag $(T)$ & Kotgadi & 29.86904 & 80.07238 & Metamorphic \\
\hline Berinag $(\mathrm{T})$ & Sheridhara/Chormania & 29.72466 & 80.07655 & Metamorphic \\
\hline Munsyari (T) & TallaDhumar & 30.10648 & 80.2506 & Metamorphic \\
\hline Munsyari (T) & Munsyari & 30.06572 & 80.23782 & Metamorphic \\
\hline Munsyari (T) & Birthi & 30.03971 & 80.16334 & Metamorphic \\
\hline Munsyari (T) & Timtia & 29.93738 & 80.14392 & Sedimentary Carbonate \\
\hline Munsyari (T) & Selmali & 29.95611 & 80.24926 & Igneous \\
\hline Pithoragarh (T) & Gethigada(Taleshwar) & 29.60914 & 80.40656 & Sedimentary \\
\hline Pithoragarh (T) & Katiyani & 29.60482 & 80.35062 & Sedimentary \\
\hline Pithoragarh (T) & Mad-Saun & 29.52389 & 80.30561 & Sedimentary \\
\hline Gangolihat (T) & Dubola & 29.52303 & 80.09117 & Metamorphic \\
\hline Gangolihat (T) & Jadapani & 29.71321 & 80.03857 & Sedimentary Carbonate \\
\hline Gangolihat (T) & JahnaviNaula & 29.6564 & 80.04267 & Sedimentary Carbonate \\
\hline
\end{tabular}

was done from April- June 2018 and for POM, the sampling was done from September- November 2017. Samples were stored at $4^{\circ} \mathrm{C}$ temperature in the laboratory and were analyzed as soon as possible after the collection and the samples collected for the analyses of uranium and other heavy metals concentration were acidified with nitric acid to $\mathrm{pH}$ 1-2.

\subsubsection{Estimation of physico- chemical parameters}

All the techniques which were adopted during the analysis of physico-chemical parameters are discussed here. For the analysis of $\mathrm{pH}$, dissolved oxygen (DO), total dissolved solids (TDS), electrical conductance (EC), oxidationreduction potential (ORP) and temperature $(T)$, water, and soil analysis kit by ISO- TECH with model no. ITS- 701 was used and suitable probes were used for afore said parameters. All these parameters were measured immediately at the sampling sites in in-situ conditions. Mohr's method was used for the analysis of chloride $\left(\mathrm{Cl}^{-}\right)$concentration in water samples. For the estimation of total hardness (TH), ammonia buffer was added to the samples followed by Eriochrome Black T as an indicator and ethylenediaminetetraacetic acid (EDTA) as titrant. Calcium (Ca) hardness was analyzed by using $\mathrm{NaOH}$, followed by murexide as an indicator and EDTA as titrant. For the estimation of total alkalinity (TA), phenolphthalein and methyl orange were used as indicators. Fluoride $\left(\mathrm{F}^{-}\right)$, nitrate $\left(\mathrm{NO}_{3}{ }^{-}\right)$, phosphate $\left(\mathrm{PO}_{4}^{-3}\right)$, and sulfate $\left(\mathrm{SO}_{4}^{-2}\right)$ were analyzed with the help of a digital multiparameter photometer with model no. HI83,300 by Hanna. For the determination of $\mathrm{F}^{-}$concentration in water samples, the SPADNS method was used, for $\mathrm{NO}_{3}^{-}$determination, cadmium reduction method, for $\mathrm{PO}_{4}^{-3}$ determination, ascorbic acid method, and for $\mathrm{SO}_{4}^{-2}$ determination, precipitation with barium chloride crystal method was used. Magnesium (Mg), Carbonate $\left(\mathrm{CO}_{3}^{-2}\right)$ and bicarbonate $\left(\mathrm{HCO}_{3}^{-}\right)$were calculated theoretically.

\subsubsection{Uranium estimation in water samples using fluorimetry}

Laser fluorimeter manufactured by Quantalase Enterprises Pvt. Ltd., Indore, was used for the analysis of uranium in drinking water samples. The analytical procedure for the determination of uranium concentration in water samples was done by adopting the procedure described by Sahoo and co-workers [12]. The source used in the study was LED and the wavelength of the laser was $400 \mathrm{~nm}$. About $5 \mathrm{~mL}$ 


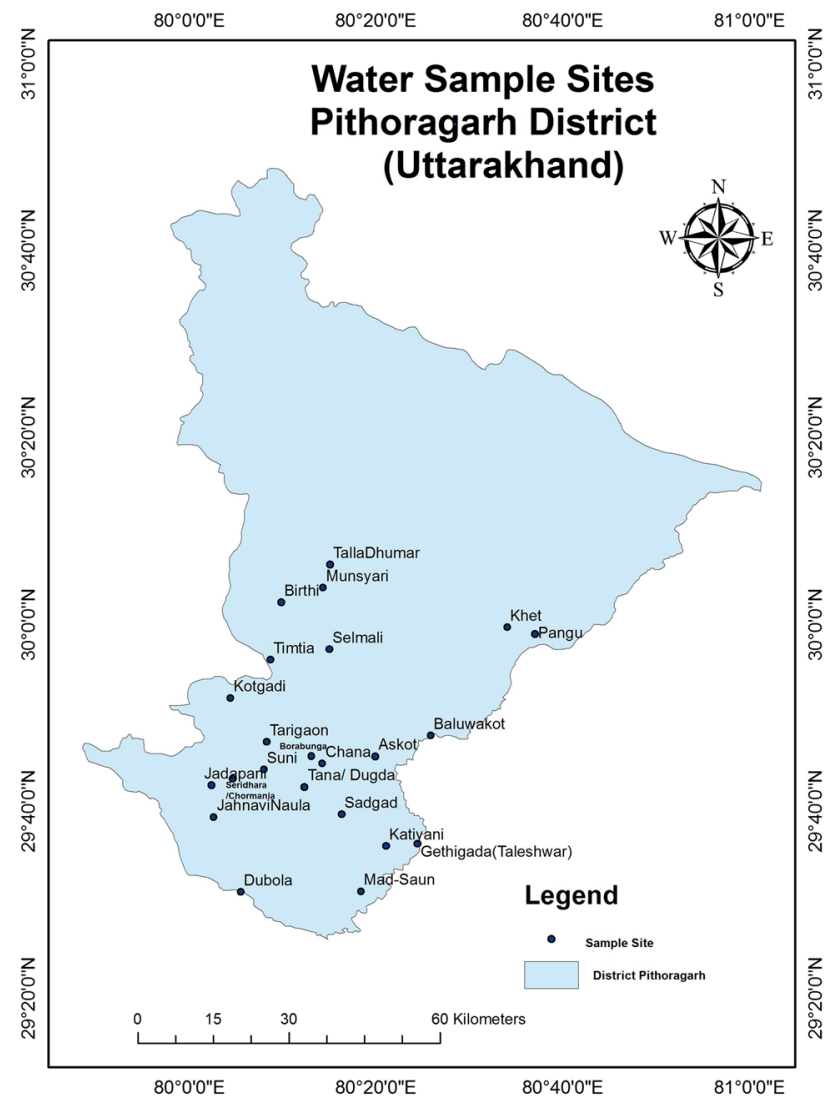

Fig. 1 Map representing sampling locations with elevation

of water sample was placed in a dry and clean cell and $0.5 \mathrm{~mL}$ of $5 \%$ sodium pyrophosphate $(\mathrm{pH} 7)$ was added and measured. The instrument was calibrated with a standard uranium solution of a known concentration. The standard addition method was followed for analysis of field samples to avoid the matrix effect because the samples were from different parts of the district and the chemical constituents may vary significantly. Micropipettes and analytical balance were used simultaneously to avoid any error in pipetting. The concentration of uranium $(U)$ in water samples using Laser fluorimeter was calculated by:

$U(p p b)=\frac{D 1}{D 2-D 1} \times \frac{V 1}{V 2} \times C$

where, $\mathrm{D}_{1}=$ Fluorescence due to sample only; $\mathrm{D}_{2}=$ Fluorescence due to sample and $U$ standard spiked; $V_{1}=$ Volume of $\mathrm{U}$ standard added $(\mathrm{mL}) ; \mathrm{V}_{2}=$ Volume of sample taken $(\mathrm{mL})$; $\mathrm{C}=$ Concentration of $\mathrm{U}$ - standard solution $\left(\mu \mathrm{g} \mathrm{L}^{-1}\right)$

\subsubsection{Heavy metal analysis}

Varian AA280Z Zeeman Atomic absorption spectrometer with GTA 120 Graphite Tube Atomizer was used for the metal (copper, lead, iron, manganese, zinc and chromium) analysis. To destroy organic material in the sample, $100 \mathrm{~mL}$ aliquot of filtered water sample was taken in duplicate for wet digestion $\left(\mathrm{HNO}_{3}\right)$ on hot plates followed by the injection of $25 \mathrm{~mL}$ of the prepared sample in the nebulizerspray chamber-burner system of the Atomic Absorption Spectrophotometer. Atomic Absorption Spectrophotometer was standardized with standard element concentrations in prior and air-acetylene compressed gas has been used as oxidant and fuel.

\section{Result and discussion}

\subsection{Uranium concentration analysis}

The samples were collected at PRM and POM seasons. This paper consists of the distribution of uranium concentration based on the tehsils of the Pithoragarh district. The uranium concentration of these 23 sampling sites varied from 0.10 to $9.96 \mu \mathrm{g} \mathrm{L}^{-1}$ in PRM and 0.10 to $8.32 \mu \mathrm{g} \mathrm{L}^{-1}$ in POM which was lower than guideline values of $30 \mu \mathrm{g} \mathrm{L}^{-1}$ by WHO and $60 \mu \mathrm{g} \mathrm{L}^{-1}$ by AERB (India), DAE (India). Three samples were collected from Dharchula tehsil for which the minimum value of uranium concentration was $0.14 \mu \mathrm{g} \mathrm{L}^{-1}$ and the maximum was $9.96 \mu \mathrm{g} \mathrm{L}^{-1}$ for the PRM period. For POM it ranged from 0.10 to $8.32 \mu \mathrm{g} \mathrm{L}^{-1}$. From Didihat tehsil, seven samples were collected, the uranium concentration ranged from 0.10 to $1.12 \mu \mathrm{g} \mathrm{L}^{-1}$ in the PRM period and 0.10 to $1.20 \mu \mathrm{g}$ $\mathrm{L}^{-1}$ in the POM period. Two samples were collected from Berinag tehsil. The concentration of uranium in the PRM period ranged from 0.25 to 0.54 and 0.12 in the POM period for both the samples. For five samples collected from Munsyari tehsil, the concentration of uranium varied from 0.17 to $2.35 \mu \mathrm{g} \mathrm{L}^{-1}$ for PRM and 0.10 to $2.76 \mu \mathrm{g}$ $\mathrm{L}^{-1}$ for POM. For three samples collected from Pithoragarh tehsil, the PRM concentration of uranium varied from 0.20 to $1.00 \mathrm{\mu} \mathrm{L}^{-1}$, and for POM, it varied from 0.11 to $0.30 \mu \mathrm{g} \mathrm{L}^{-1}$. For three samples collected from Gangolihat tehsil, the uranium concentration varied from 0.10 to $0.22 \mu \mathrm{g} \mathrm{L}^{-1}$ during PRM and 0.10 to $0.23 \mu \mathrm{g} \mathrm{L}^{-1}$ during POM. All the collected samples with their uranium concentration and average values are represented in Table 2, and the distribution of uranium concentration in PRM and POM seasons is represented in Figs. 2 and 3. Among all the samples, the highest value of uranium concentration was obtained from only one sample collected from a specific site in Dharchula tehsil in both PRM and POM seasons; although, this value is still below the prescribed limit of $30 \mu \mathrm{g} \mathrm{L}^{-1}$. The higher value of uranium in the sample collected from a particular specific site of Dharchula could be due to the presence of igneous rocks in that region 
Table 2 Distribution of uranium concentration at different locations of Pithoragarh district

\begin{tabular}{|c|c|c|c|c|c|c|c|}
\hline \multirow[t]{3}{*}{ Tehsil (T) } & \multirow[t]{3}{*}{ No. of samples } & \multicolumn{6}{|c|}{ Uranium concentration $\left(\mu \mathrm{g} \mathrm{L}^{-1}\right)$} \\
\hline & & \multicolumn{3}{|l|}{ PRM } & \multicolumn{3}{|l|}{ POM } \\
\hline & & Min & Max & Average & Min & Max & Average \\
\hline Dharchula (T) & 3 & 0.14 & 9.96 & 3.64 & 0.10 & 8.32 & 3.14 \\
\hline Didihat $(\mathrm{T})$ & 7 & 0.10 & 1.12 & 0.37 & 0.10 & 1.20 & 0.26 \\
\hline Berinag $(T)$ & 2 & 0.25 & 0.54 & 0.39 & 0.12 & 0.12 & 0.12 \\
\hline Munsyari (T) & 5 & 0.17 & 2.35 & 1.03 & 0.10 & 2.76 & 1.06 \\
\hline Pithoragarh (T) & 3 & 0.20 & 1.00 & 0.57 & 0.11 & 0.30 & 0.23 \\
\hline Gangolihat (T) & 3 & 0.10 & 0.22 & 0.14 & 0.10 & 0.23 & 0.15 \\
\hline
\end{tabular}

Fig. 2 Distribution of uranium $\left(\mu \mathrm{g} \mathrm{L}^{-1}\right)$ in pre- monsoon

\section{Urnaium concentration in pre- monsoon}

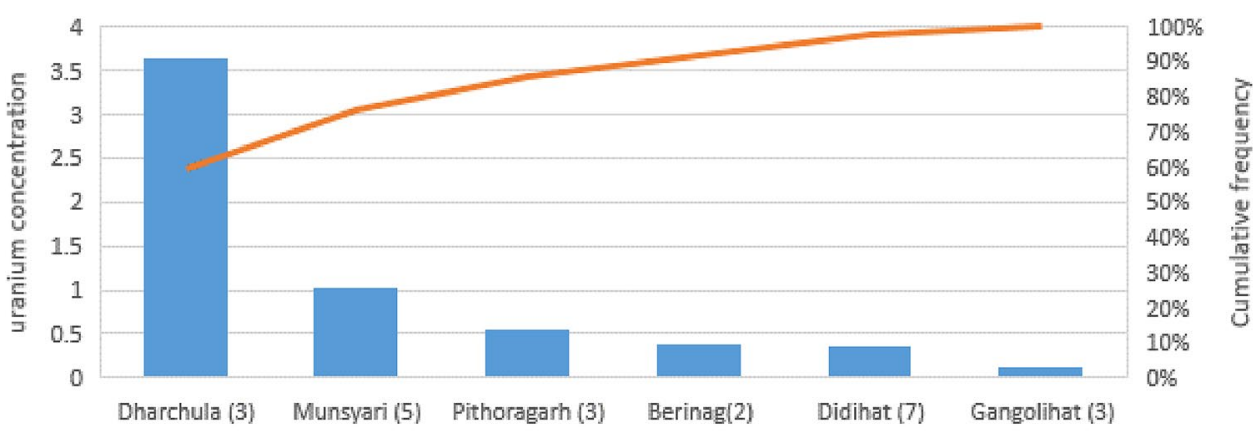

Tehsils

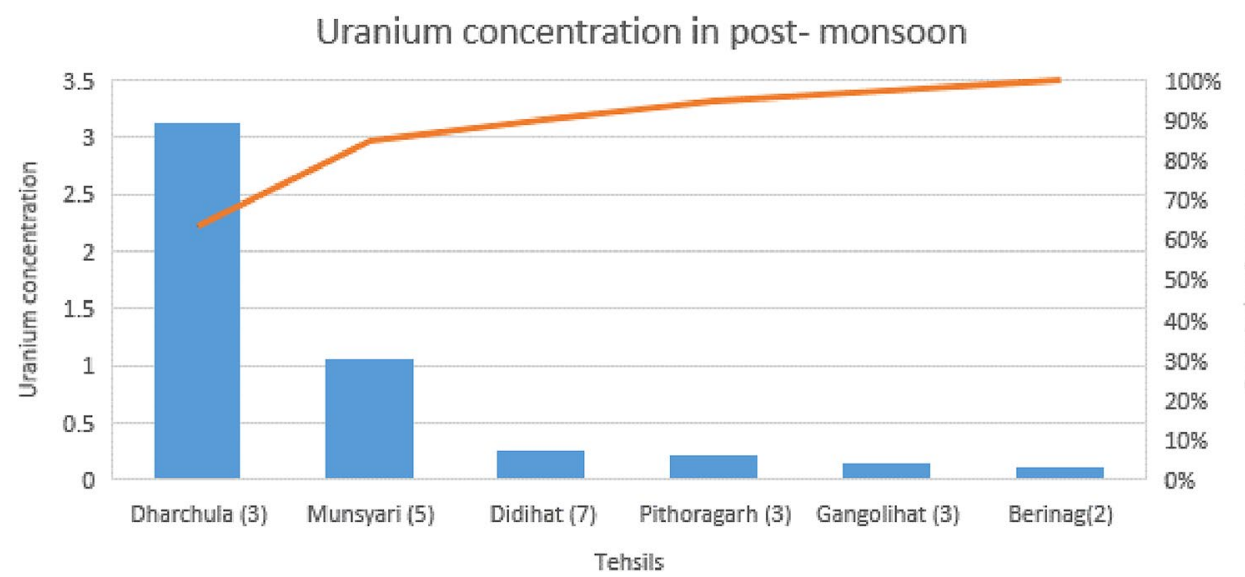

Fig. 3 Distribution of uranium $\left(\mu \mathrm{g} \mathrm{L}^{-1}\right)$ in post- monsoon. *In both the figures, the number in the bracket represents the number of samples collected from the respective tehsil

\subsection{Water quality parameters}

radionuclides like uranium in water depends upon its concentration in rocks and soil. Igneous rocks are usually those types of rocks that have a higher concentration of radionuclides like uranium in comparison to other kinds of rocks [7, 21]. Thus, by analysis of different samples collected from different sites in the Tehsils and sub tehsils of Pithoragarh, it was found that the uranium concentration was found to be lower than the guideline values prescribed by both WHO and AERB (India).
The summarized statistical analysis of the physicochemical parameters of water samples is represented in Table 3. The $\mathrm{pH}$ was found to be acidic to alkaline in both seasons. TDS ranged from 30.00 to $624.00 \mathrm{mg} / \mathrm{L}$ and 25.70 to $604.00 \mathrm{mg} / \mathrm{L}$ during PRM and POM respectively. The maximum value of nitrate was found to be $46.70 \mathrm{mg} / \mathrm{L}$ in PRM and $61.50 \mathrm{mg} / \mathrm{L}$ in POM which is greater than the prescribed Bureau of Indian Standards (BIS) limit which may be due to leaching from plant 
Table 3 The statistical summary of water samples

\begin{tabular}{|c|c|c|c|c|c|c|c|c|c|c|}
\hline \multirow[t]{2}{*}{ Parameters } & \multicolumn{5}{|c|}{$\operatorname{PRM}(\mathrm{N}=23)$} & \multicolumn{5}{|c|}{ POM $(\mathrm{N}=23)$} \\
\hline & Min & Max & Average & $\begin{array}{l}\text { Standard } \\
\text { deviation }\end{array}$ & Skewness & Min & Max & Average & $\begin{array}{l}\text { Standard } \\
\text { deviation }\end{array}$ & Skewness \\
\hline $\mathrm{pH}$ & 5.87 & 8.56 & 7.39 & 0.67 & -0.36 & 5.63 & 8.43 & 7.29 & 0.60 & -0.85 \\
\hline TDS (mg/L) & 30.00 & 624.00 & 204.65 & 169.46 & 0.69 & 25.70 & 604.00 & 213.82 & 175.02 & 0.73 \\
\hline $\mathrm{EC}(\mu \mathrm{S} / \mathrm{Cm})$ & 34.80 & 950.00 & 309.26 & 254.30 & 0.72 & 38.80 & 909.00 & 321.63 & 262.36 & 0.72 \\
\hline $\mathrm{ORP}( \pm \mathrm{mV})$ & 119.00 & 280.00 & 214.83 & 48.38 & -0.37 & 85.00 & 263.00 & 152.32 & 50.01 & 0.58 \\
\hline $\mathrm{T}\left({ }^{\circ} \mathrm{C}\right)$ & 16.3 & 25.3 & 20.4 & 2.4 & 0.33 & 15.3 & 26.0 & 19.8 & 3.2 & 0.43 \\
\hline $\mathrm{DO}(\mathrm{mg} / \mathrm{L})$ & 4.8 & 8.5 & 6.9 & 1.3 & -0.23 & 5.4 & 9.6 & 7.5 & 1.4 & -0.52 \\
\hline $\mathrm{F}^{-}(\mathrm{mg} / \mathrm{L})$ & 0.005 & 1.80 & 0.22 & 0.40 & 3.36 & 0.005 & 2.00 & 0.40 & 0.54 & 2.57 \\
\hline $\mathrm{Cl}^{-}(\mathrm{mg} / \mathrm{L})$ & 42.54 & 106.35 & 66.89 & 16.94 & 0.81 & 28.36 & 99.26 & 51.33 & 16.55 & 1.32 \\
\hline $\mathrm{NO}_{3}{ }^{-}(\mathrm{mg} / \mathrm{L})$ & 0.05 & 46.70 & 3.00 & 10.01 & 4.16 & 0.05 & 61.5 & 6.41 & 13.07 & 4.18 \\
\hline $\mathrm{SO}_{4}^{-2}(\mathrm{mg} / \mathrm{L})$ & 0.5 & 32.5 & 5.9 & 8.1 & 2.1 & 1.0 & 40.0 & 8.0 & 10.8 & 2.1 \\
\hline $\mathrm{PO}_{4}^{-3}(\mathrm{mg} / \mathrm{L})$ & 0.005 & 0.70 & 0.11 & 0.17 & 2.39 & 0.005 & 0.45 & 0.14 & 0.13 & 1.16 \\
\hline $\mathrm{TH}(\mathrm{mg} / \mathrm{L})$ & 32.00 & 352.00 & 155.48 & 106.59 & 0.45 & 24.00 & 360.00 & 140.48 & 106.92 & 0.73 \\
\hline $\mathrm{Ca}(\mathrm{mg} / \mathrm{L})$ & 3.84 & 20.52 & 10.71 & 5.24 & 0.31 & 2.56 & 33.35 & 12.62 & 8.79 & 1.02 \\
\hline $\mathrm{Mg}(\mathrm{mg} / \mathrm{L})$ & 4.66 & 74.66 & 31.29 & 23.40 & 0.52 & 1.94 & 67.25 & 26.39 & 21.85 & 0.81 \\
\hline TA (mg/L) & 48.0 & 336.0 & 157.6 & 85.9 & 0.39 & 8.0 & 376.0 & 160.9 & 114.0 & 0.44 \\
\hline $\mathrm{CO}_{3}^{-2}(\mathrm{mg} / \mathrm{L})$ & 0 & 128 & 13.91 & 38.38 & 2.68 & 0 & 96 & 10.24 & 23.55 & 3.37 \\
\hline $\mathrm{HCO}_{3}{ }^{-}(\mathrm{mg} / \mathrm{L})$ & 32.0 & 336.0 & 143.6 & 86.0 & 0.63 & 8.0 & 376.0 & 154.6 & 106.8 & 0.4 \\
\hline
\end{tabular}

nutrient and use of nitrogen-containing fertilizer. Fluoride in some samples was slightly high in both seasons. High or low concentrations of fluoride in water may be due to natural as well as anthropogenic reasons. Natural causes are associated with the geological, physical, and chemical conditions, soil, and rock types of the study area. Fluoride is a lithophilic element that occurs in many common rock minerals like fluorite, apatite, etc. [22, 23]. $\mathrm{Mg}$ was higher in both the seasons which might have been introduced from the dissolution of magnesium calcite, gypsum, and dolomite from the source rock. Total hardness of the water samples ranged from 32.00 to $352.00 \mathrm{mg} / \mathrm{L}$ with the average value of $155.48 \mathrm{mg} / \mathrm{L}$ in PRM and 24.00 to $360.00 \mathrm{mg} / \mathrm{L}$ with the average value of $140.48 \mathrm{mg} / \mathrm{L}$ in POM.

\subsection{Heavy metal analysis}

Heavy metals are toxic elements that are bioaccumulative. These can be toxic if taken in the excess amount than the required concentration and can enter the body through drinking, inhalation, ingestion, and skin absorption [24]. Different metals like copper, lead, iron, manganese, zinc, and chromium were evaluated in the collected water samples and the evaluated concentration of the samples is given in Table 4 and their seasonal variation is shown in Figs. 4 and 5.

Copper is an essential metal for humans but if taken in excess, it causes anemia, stomach, and intestinal irritation. Along with this, it can also cause liver and kidney problems. In the present study, the concentration of

Table 4 Seasonal representation of metals

\begin{tabular}{lllll}
\hline Metals & PRM & POM & \multicolumn{2}{l}{ Desirable limit(mg/L) } \\
\cline { 3 - 4 } & & & $\begin{array}{l}\text { (Recommended by } \\
\text { BIS) [28] }\end{array}$ & $\begin{array}{l}\text { Permissible limit(mg/L) } \\
\text { (Recommended by BIS) }\end{array}$ \\
\hline Copper $(\mathrm{Cu})(\mathrm{mg} / \mathrm{L})$ & $<0.00001^{*}-0.0031$ & $<0.00001-0.0031$ & 0.05 & 1.5 \\
Lead $(\mathrm{Pb})(\mathrm{mg} / \mathrm{L})$ & $<0.00001-0.012$ & $<0.010-0.010$ & 0.01 & No relaxation \\
Iron $(\mathrm{Fe})(\mathrm{mg} / \mathrm{L})$ & $<0.01-0.80$ & $<0.01-0.64$ & 0.3 & No relaxation \\
Manganese $(\mathrm{Mn})(\mathrm{mg} / \mathrm{L})$ & $0.002-0.010$ & $0.002-0.010$ & 0.1 & 0.3 \\
Zinc $(\mathrm{Zn})(\mathrm{mg} / \mathrm{L})$ & $0.01-0.22$ & $0.01-0.12$ & 5 & 15 \\
Cromium $(\mathrm{Cr})(\mathrm{mg} / \mathrm{L})$ & $<0.01$ & $<0.01$ & 0.05 & No relaxation
\end{tabular}

$<0.00001$ indicates all those values which were below detection limit 
Fig. 4 Seasonal variation of $\mathrm{Cu}$ and $\mathrm{Pb}(\mathrm{mg} / \mathrm{L})$
Seasonal variation of average value of $\mathrm{Cu}$ and $\mathrm{Pb}$

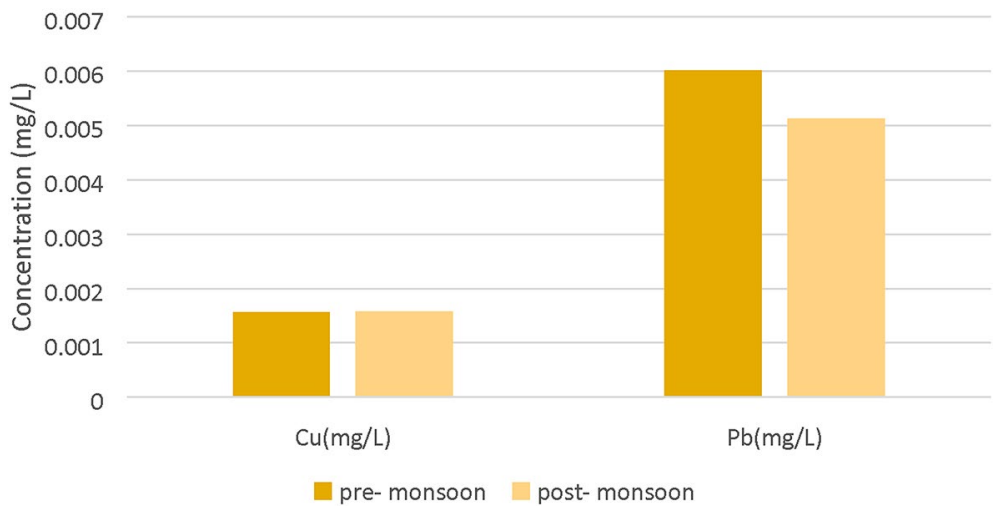

Seasonal variation of $\mathrm{Fe}, \mathrm{Mn}, \mathrm{Zn}$ and $\mathrm{Cr}$

$\mathrm{Mn}, \mathrm{Zn}$ and $\mathrm{Cr}(\mathrm{mg} / \mathrm{L})$

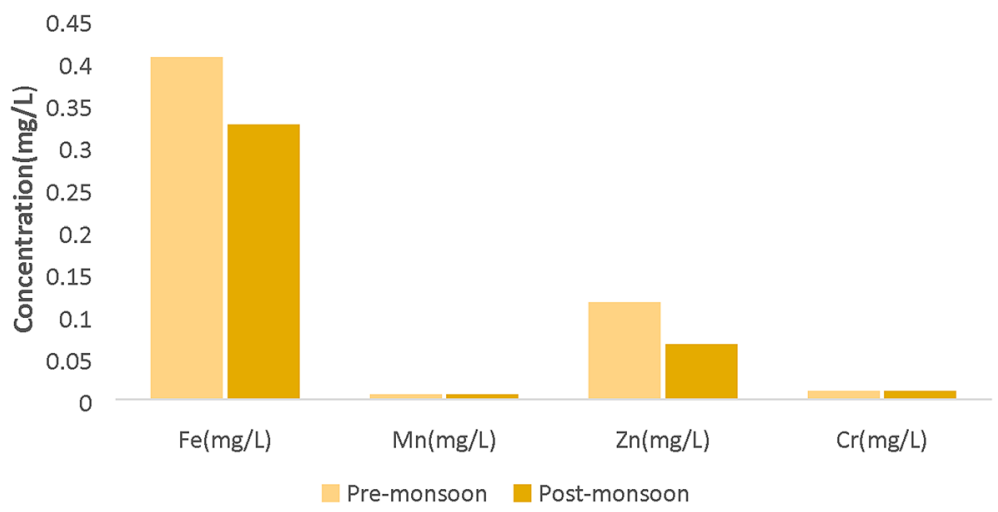

also, a high concentration of iron in rivers of Uttarakhand was reported [25]. This increase in the value may be due to geological reasons [26]. Weathering of rocks can be one of the reasons for iron contamination. High iron content in drinking water may cause 'Haemosiderosis' [27]. Mn was found to be $0.002-0.010 \mathrm{mg} / \mathrm{L}$ in both the seasons. Zinc concentration in water varied from $<0.01$ to $0.22 \mathrm{mg} / \mathrm{L}$ in pre-monsoon and from 0.01 to $0.12 \mathrm{mg} / \mathrm{L}$ in post-monsoon season. Long-term exposure to chromium is carcinogenic and can cause respiratory
Table 5 Correlation table between uranium and metals during pre-monsoon season

\begin{tabular}{lccccccc}
\hline & $\mathrm{Cu}(\mathrm{mg} / \mathrm{L})$ & $\mathrm{Pb}(\mathrm{mg} / \mathrm{L})$ & $\mathrm{Fe}(\mathrm{mg} / \mathrm{L})$ & $\mathrm{Mn}(\mathrm{mg} / \mathrm{L})$ & $\mathrm{Zn}(\mathrm{mg} / \mathrm{L})$ & $\mathrm{Cr}(\mathrm{mg} / \mathrm{L})$ & $\mathrm{U}(\mu \mathrm{g} / \mathrm{L})$ \\
\hline $\mathrm{Cu}(\mathrm{mg} / \mathrm{L})$ & 1 & & & & & & \\
$\mathrm{~Pb}(\mathrm{mg} / \mathrm{L})$ & 0.23 & 1 & & & & & \\
$\mathrm{Fe}(\mathrm{mg} / \mathrm{L})$ & 0.18 & 0.12 & 1 & & & \\
$\mathrm{Mn}(\mathrm{mg} / \mathrm{L})$ & 0.14 & -0.10 & $0.64^{* *}$ & 1 & & \\
$\mathrm{Zn}(\mathrm{mg} / \mathrm{L})$ & 0.28 & 0.15 & $0.55^{* *}$ & $0.67^{* *}$ & 1 & \\
$\mathrm{Cr}(\mathrm{mg} / \mathrm{L})$ & 0.00 & 0.00 & 0.00 & 0.00 & 0.00 & 1 & \\
$\mathrm{U}(\mu \mathrm{g} / \mathrm{L})$ & -0.15 & -0.04 & -0.13 & -0.18 & -0.16 & 0.00 & 1 \\
\hline
\end{tabular}

** Correlation is significant at the 0.01 level (2-tailed) 
Table 6 Correlation table between uranium and metals during post- monsoon season

\begin{tabular}{lcclllll}
\hline & $\mathrm{Cu}(\mathrm{mg} / \mathrm{L})$ & $\mathrm{Pb}(\mathrm{mg} / \mathrm{L})$ & $\mathrm{Fe}(\mathrm{mg} / \mathrm{L})$ & $\mathrm{Mn}(\mathrm{mg} / \mathrm{L})$ & $\mathrm{Zn}(\mathrm{mg} / \mathrm{L})$ & $\mathrm{Cr}(\mathrm{mg} / \mathrm{L})$ & $\mathrm{U}(\mu \mathrm{g} / \mathrm{L})$ \\
\hline $\mathrm{Cu}(\mathrm{mg} / \mathrm{L})$ & 1 & & & & & & \\
$\mathrm{~Pb}(\mathrm{mg} / \mathrm{L})$ & -0.02 & 1 & & & & & \\
$\mathrm{Fe}(\mathrm{mg} / \mathrm{L})$ & 0.08 & $0.44^{*}$ & 1 & & & & \\
$\mathrm{Mn}(\mathrm{mg} / \mathrm{L})$ & 0.04 & $0.43^{*}$ & $0.62^{* *}$ & 1 & & \\
$\mathrm{Zn}(\mathrm{mg} / \mathrm{L})$ & 0.12 & 0.16 & $0.48^{*}$ & $0.68^{* *}$ & 1 & \\
$\mathrm{Cr}(\mathrm{mg} / \mathrm{L})$ & 0.00 & 0.00 & 0.00 & 0.00 & 0.00 & 1 & \\
$\mathrm{U}(\mu \mathrm{gg} / \mathrm{L})$ & -0.15 & -0.08 & 0.00 & -0.02 & -0.05 & 0.00 & 1 \\
\hline
\end{tabular}

${ }^{*}$ Correlation is significant at the 0.05 level (2-tailed)

**Correlation is significant at the 0.01 level (2-tailed) problems. In the present study, chromium was recorded below the detection limit in both seasons.

\subsection{Correlation analysis between uranium concentration and metals}

Correlation analysis was done to assess the correlation between various metals analyzed here and uranium concentration. The correlation table for both the pre-monsoon and post-monsoon seasons are given in Tables 5 and 6 . A negative correlation has been exhibited by uranium with most of the metals with $\mathrm{Cu}(-0.15), \mathrm{Pb}(-0.04), \mathrm{Fe}(-0.13)$, $\mathrm{Mn}(-0.18), \mathrm{Zn}(-0.16)$ during pre-monsoon and with $\mathrm{Cu}$ $(-0.15), \mathrm{Pb}(-0.08), \mathrm{Mn}(-0.02)$ and $\mathrm{Zn}(-0.05)$ during post-monsoon.

\section{Conclusion}

The chemical composition of water is strongly influenced by the geology of the surroundings, weathering and leaching actions of water, and the use of fertilizers. The above study gives an overview of the quality of water samples collected from the Pithoragarh district. Physico-chemical parameters and heavy metals were also found to be within the range except for a few parameters $\left(\mathrm{F}-, \mathrm{NO}_{3}{ }^{-}, \mathrm{Mg}\right.$, and $\mathrm{Fe}$ ). The $\mathrm{pH}$ of some of the samples was a little acidic which can be easily treated by using alkaline methods for drinking purposes. It was found that the uranium concentration level in all the samples was within WHO guideline values $\left(30 \mu \mathrm{g} \mathrm{L}^{-1}\right)$ and indicates that there is a natural distribution of uranium in water. Along with this, the correlation study of uranium with different metals suggests that there is no significant relationship between the uranium concentration and presence of metals in the sampling sites. Although the samples don't have a very high concentration of the parameters studied, there is a great urge to monitor these sources from time to time to confirm the potability status of water because if the concentration of these parameters increases continuously, it will cause severe health effects to the local population.

\section{Compliance with ethical standards}

Conflicts of interest The authors declare that they have no conflict of interest.

\section{References}

1. Alemu ZA, Teklu KT, Alemayehu TA, Balcha KH, Mengesha SD (2015) Physicochemical quality of drinking water sources in Ethiopia and its health impact: a retrospective study. Environ Syst Res 4:22. https://doi.org/10.1186/s40068-015-0049-7

2. Simiyu G, Ngetich J, Esipila TA (2009) Assessment of spring water quality and quantity, and health implications in Tongaren division, Nzoia River catchment, Kenya. Afr J Ecol 47:99-104. https ://doi.org/10.1111/j.1365-2028.2008.01055.x

3. Raghavendra T, Ramakrishna SUB, Vijayalakshmi T, Himabindu $V$, Arunachalam J (2014) Assesment of radon concentration and extreme gamma radiatiom level in the environs of the proposed uranium mine at Peddagattu and Seripally regions, Andhra Pradesh. J Radiat Res Appl Sc 7:269-273

4. Rani A, MehraR DV, Balarama V (2013) Analysis of uranium, concentration in drinking water samples using ICPMS. Health Phys 104:251-255. https://doi.org/10.1097/HP.0b013e318279ba05

5. Singh M, Garg VK, Gautam YP, Kumar A (2016) Spatial mapping of uranium in groundwater and risk assessment around an atomic power station in India. Environ Eng Manag J 15:783-790

6. ATSDR (2013) Toxicological Profile for Uranium, U.S. Department of Health and Human Services, Agency for Toxic Substances and Disease Registry, Atlanta, Georgia

7. Narang S, Kumar D, Kumar A (2018) Health- related analysis of uranium in Fazilka district, Punjab, India. Curr Sci 15:2079-2084

8. Bajwa BS, Kumar S, Singh S, Sahoo SK, Tripathi RM (2017) Uranium and other heavy toxic elements distribution in the drinking water samples of SW- Punjab, India. J Radiat Res Appl Sci 10:13-19. https://doi.org/10.1016/j.jrras.2015.01.002

9. Aswood MS, Jaafar MS, Salih N (2017) Estimation of annual effective dose due to natural radioactivity in ingestion of vegetables from Cameron Highlands, Malaysia. Environ Technol Innov 8:96-102. https://doi.org/10.1016/j.eti.2017.05.004

10. AERB (2004) Drinking water specifications in India. Department of Atomic Energy, Govt. of India 
11. WHO (2011) Guidelines for drinking-water quality, 4th edn. World Health Organization, Geneva

12. Sahoo SK, Mohapatra S, Chakrabarty A, Sumesh CG, Jha VN, Tripathi RM, Puranik VD (2009) Distribution of uranium in drinking water and associated age dependent radiation dose in India. Radiat Prot Dosim 136:108-113

13. Sethy NK, Tripathi RM, Jha VN, Sahoo SK, Shukla AK, Puranik VD (2011) Assessment of natural uranium in the ground water around Jaduguda uranium mining complex, India. J Environ Prot 2:1002-1007

14. Bhangare RC, Tiwari M, Ajmal PY, Sahu SK, Pandit GG (2013) Laser flourimetric analysis of uranium in water from Vishakhapatnam and estimation of health risk. Radiat Protect Environ 36:128-132

15. Sharma N, Singh J (2016) Radiological and chemical risk assessment due to high uranium contents observed in the ground waters of Mansa District (Malwa Region) of Punjab State, India: an area of high cancer incidence. Expo. Health 8:513-525. https ://doi.org/10.1007/s12403-016-0215-9

16. Sar SK, Diwan V, Biswas S, Singh S, Sahu M, Jindal MK, Arora A (2017) Study of uranium level in groundwater of Balod district of Chhattisgarh state, India and assessment of health risk. Human Ecol Risk Assess Int J 24:691-698. https://doi.org/10.1080/10807 039.2017.1397498

17. Sharma T, Sharma A, Kaur I, Mahajan RK, Litoria PK, Sahoo SK, Bajwa BS (2019) Uranium distribution in groundwater and assessment of age dependent radiation dose in Amritsar, Gurdaspur and Pathankot districts of Punjab, India. Chemosphere 219:607-616. https://doi.org/10.1016/j.chemospher e.2018.12.039

18. Sahu M, Sar SK, Baghel T, Dewangan R (2020) Seasonal and geochemical variation of uranium and major ions in groundwater at Kanker district of Chhattisgarh, central India. Groundw Sustain Dev 10:1-9. https://doi.org/10.1016/j.gsd.2020.100330
19. Verma R (2013) Water and fishery resources of Kumaun Central Himalaya, India. Discovery 8:7-12

20. Sheikh MA, Dar IY, Yaseen S, Pal A, Pandit AK (2013) A study of physico-chemical characteristics of three fresh water springs of Kashmir Himalaya, India. Int J Water Res Environ Eng 5:328-331

21. Lima M, Sanchez JS, Alves C (2017) Assessment of portable gamma spectrometry of external gamma radiation hazard due to granitic materials and indoor space typology. Geoscience 7:131. https://doi.org/10.3390/geosciences7040131

22. Brindha $K$, Elango L (2011) Fluoride in groundwater: causes, implications and mitigation measures. In: Monroy, S.D. (Ed.), Fluoride properties, applications and environmental management. Nova Science Publishers. pp 111-136

23. Kumar A, Kumar V (2015) Fluoride contamination in drinking water and its impact on human health of Kishanganj, Bihar, India. Res J Chem Sci 5:76-84

24. Gaur S, Joshi MC, Saxena SK, Dutt HK (2011) Analytical study of water safety parameters in ground water samples of Uttarakhand in India. Asian J Biomed Pharm Sci 1:166-169

25. Seth R, Mohan M, Singh P, Singh R, Dobhal R, Singh KP, Gupta S (2016) Water quality evaluation of Himalayan rivers of Kumaun region, Uttarakhand, India. Appl Water Sci 6:137-147

26. Raju NJ (2006) Iron contamination in ground water: a case from Tirumala- Tirupati environs, India. Res Commun 1:32-35

27. Rajappa B, Manjappa S, Puttaiah ET (2010) Monitoring of heavy metal concentration in groundwater of Hakinaka Taluk, India. Contemp Eng Sci 3:183-190

28. Indian Standard IS 10500 (2012) Drinking water-specification (Second Revision) pp 2-3

Publisher's Note Springer Nature remains neutral with regard to jurisdictional claims in published maps and institutional affiliations. 